\title{
Experimental Research on Testing Methods of Innovating in vitro Grafting of Cherry (Prunus sp.)
}

\author{
Oana LIVADARIU* \\ Faculty of Biotechnology, University of Agronomic Science and Veterinary Medicine Bucharest, 59 \\ Mărăşti Bd., 011464 Bucharest, Romania \\ *Corresponding author, email: ombioteh@gmail.com
}

Bulletin UASVM Animal Science and Biotechnologies 71(2) / 2014,

Print ISSN 1843-5262; Electronic ISSN 1843-536X

DOI:10.15835/buasvmcn-asb:10318

\begin{abstract}
The experiments presented in this scientific paper were conducted with the aim of testing methods of innovating in vitro grafting of cherry (Prunus sp.), to obtain grafted vitroplants that can be used to establish efficient orchards in Romania. The primary source of inoculum for the biological vegetable material was the apical vegetative cherry buds (Prunus sp.), for both rootstock varieties (Mazzard and Gisela 6) and scion varieties (Stella, Severin, Rubin). The experimental scheme included eighteen experimental variants carried depending on the grafting method, the rootstock variety and scion variety. The Gisela 6 rootstock variety allowed obtaining the highest number of grafted vitroplants with each of the three scion varieties, through both M3 method and M2 method. Also, the Rubin scion variety allowed obtaining the highest number of vitroplants grafted independently of the rootstock variety, thorough both M3 method and M2 method. The M3 method yielded the best experimental results for both grafted vitroplants consisting of Gisela 6 rootstock and Rubin scion and those consisting of Gisela 6 rootstock and Severin scion. The experimental variant that yielded the best experimental results consisted of method M3, Gisela 6 rootstock and Rubin scion.

The results of the experimental research presented in this scientific paper demonstrates that testing methods of innovating in vitro grafting of cherry (Prunus sp.), is feasible to obtain grafted vitroplants that can be used to establish efficient orchards in Romania.
\end{abstract}

Keywords: cherry, in vitro grafting, Prunus sp., rootstock, scion

\section{INTRODUCTION}

In vitro grafting is one of the techniques through which modern biotechnology can provide practical solutions to obtain vitroplants. These vitroplants have a phenotypic unitary structure (grafted vitroplant), formed by the union, communication and cooperation between the two phenotypic subunitary structures (scion and rootstock).

Depending on the ultimate goal of the experiment (obtaining seedlings / saplings to establish vegetable crops or plantations / orchards, obtaining fruits / vegetables for fresh or processed consumption), the scion and the rootstock must provide the grafted vitroplant with both better capacity to adapt to the environment and higher quality of vegetables / fruits. Thus, obtaining and cultivating grafted vitroplants make possible both more optimal exploitation of natural resources and more effective marketing of vegetables and fruits, regionally and globally.

Among the plants enshrined as the tree species grown in intensive plantations (apple, plum, cherry, pear, apricot, peach, walnut, etc.) at the level of the fruit tree sector in Romania (Dejeu et al., 1997; Chira and Asănică, 2010), we selected the cherry (Prunus sp.), taking into account both the existence of favorable conditions to realize its agrobiological potential and its economic importance (Chira and Asănică, 2010).

Taking into account the cherry (Prunus sp.), production obtained, the trading price and its size of share of trade at regional and global level in the last decade, the cherry (Prunus sp.), generates the 
need for rejuvenation and expansion of the existing orchards. This need is increased by the downward trend in cherry (Prunus sp.), production in the European Union as compared to Asia and the United States whose productions tend to increase (FAO, 2013).

Cherry (Prunus sp.) is a fruit tree which can be used both in food industry for the fresh or processed fruits (as juice, sauce, jam, marmalade, pastries) and in biotherapy for fresh fruits (to treat constipation, obesity, atherosclerosis, gallstones, gout, high blood pressure, etc.), and for stalks of mature fruits (as diuretic tea). Furthermore, cherry trees (Prunus sp.), can be valorised as wood in the furniture industry (as veneer) in beekeeping for nectar and pollen (medium economic - apicultural weight) in cosmetics for fruits (to restore skin elasticity), and in landscape architecture due to its abundant flowers and height of the tree (Chira and Asănică, 2010; Pârvu, 1999).

Additionally, in the case of the cherry tree (Prunus sp.), in vitro grafting ensures the use and production of biological material that is genetically uniform, as compared to ex vitro grafting that (for certain varieties - Mazzard, Stones Dönissen, etc.), due to the conventional propagation methods that use seeds, can not ensure at all times genetic uniformity.

There is a series of scientific papers containing information about the possibilities of obtaining cherry vitroplants (Prunus sp.), through both rooted shoots (Hammatt and Grant, 1996/1997; Tang et al., 2002; Bhagwat and Lane 2004; Canli and Tian, 2008; Liu and Pijut, 2008; Ružić et al., 2013; Clapa et al., 2013), and shoots genetically transformed via Agrobacterium tumefaciens and rooted (Wang and Piju, 2014).

The specialized literature we have covered mentions achieving in vitro grafting of cherry (Prunus sp.), between Prunus avium L. 'Regina' as scion and ' $P$ iku ${ }^{\circledR} 1$ ' $[$ P. avium $\times(P$. canescens $\times P$. tomentosa)] -as rootstock (Bourrain and Charlot, 2014), and between Prunus avium 'Seeyahe Mashad' -as scion and Prunus cerasus 'Albaloo' -as rootstock obtained by seed germination (Amiri, 2006). However, because the phenomenon of graft incompatibility between cherry varieties (Prunus sp.) represents a recognized problem, the need to study in vitro grafting between varieties that exploit specific soil and climatic conditions (Kappel et al., 2012), is obvious.
Therefore, the experimental research presented in this scientific paper is conducted with the aim of testing the methods of innovating in vitro grafting of cherry (Prunus sp.) from two rootstock varieties (Mazzard and Gisela 6) and three scion varieties (Stella, Severin, Rubin) to obtain grafted vitroplants that can be used to establish efficient orchards in Romania.

\section{MATERIALS AND METHODS}

The biological vegetable material used in the experimental research on testing methods of innovating in vitro grafting of cherry (Prunus sp.) was obtained from commercial sources and consisted of two rootstock varieties (Mazzard and Gisela 6) recognized for the great strength they give to the grafted plants (Chira and Asănică, 2010; Zorić et al., 2012), and three scion varieties (Stella, Severin, Rubin). The main criterion for selecting rootstock varieties was the level of compatibility with other cherry varieties (Prunus sp.). The main criterion for distinguishing between the two selected rootstock varieties was the multiplication method, namely: the generative method for Mazzard (Prunus avium L.), and the vegetative method for Gisela 6 (Prunus cerasus L. var. Schattenmorelle x Prunus canescens) - Chira and Asănică (2010).

The main criterion for selecting the scion varieties was the fruit quality, namely: large, red fruit with hard, sweet pulp. Each of the three scion varieties was chosen according to a principal element of differentiation, namely: their capacity for self-pollination and pollination for other varieties (Stella), high constant production (Severin), and the middle-high type vigor (Rubin).

The primary source of inoculum consisted of, for both rootstock varieties and the scion varieties, apical vegetative buds collected from medium cherry branches (Prunus sp.).

The experimental scheme used included eighteen experimental variants (Tab.1). Each experimental variant was repeated three times and each repetition consisted of 20 inocula. The experimental determinations were individually recorded for each inoculum.

The method of surface aseptisating of the biological vegetal material consisted of immersing the apical vegetative buds successively into the ethyl alcohol solution $\left(\mathrm{C}_{6} \mathrm{H}_{12} \mathrm{O}_{6}\right) 80 \%$ for 30 sec. and into sodium 
Tab. 1. Experimental variants used in testing methods of innovating in vitro grafting of cherry (Prunus sp.)

\begin{tabular}{|c|c|c|c|c|c|c|}
\hline \multirow{2}{*}{$\begin{array}{l}\text { Experimental } \\
\text { variants }\end{array}$} & \multicolumn{2}{|c|}{ The rootstock varieties } & \multicolumn{3}{|c|}{ The scion varieties } & \multirow{2}{*}{$\begin{array}{c}\text { Methods } \\
\text { of in vitro } \\
\text { grafting }\end{array}$} \\
\hline & Mazzard & Gisela 6 & Stella & Severin & Rubin & \\
\hline M1V 1 & - & & $\bullet$ & & & M1 \\
\hline M1V 2 & & & & - & & M1 \\
\hline M1V 3 & & & & & $\bullet$ & M1 \\
\hline M1V 4 & & $\bullet$ & $\bullet$ & & & M1 \\
\hline M1V 5 & & & & - & & M1 \\
\hline M1V 6 & & & & & $\bullet$ & M1 \\
\hline M2V 1 & $\bullet$ & & $\bullet$ & & & M2 \\
\hline M2V 2 & & & & - & & M2 \\
\hline M2V 3 & & & & & $\bullet$ & M2 \\
\hline M2V 4 & & $\bullet$ & $\bullet$ & & & M2 \\
\hline M2V 5 & & & & - & & M2 \\
\hline M2V 6 & & & & & $\bullet$ & M2 \\
\hline M3V 1 & $\bullet$ & & $\bullet$ & & & M3 \\
\hline M3V 2 & & & & - & & M3 \\
\hline M3V 3 & & & & & $\bullet$ & M3 \\
\hline M3V 4 & & $\bullet$ & $\bullet$ & & & M3 \\
\hline M3V 5 & & & & - & & M3 \\
\hline M3V 6 & & & & & - & M3 \\
\hline
\end{tabular}

hypochlorite solution ( $\mathrm{NaClO}$ ) $1.5 \%$ for $30 \mathrm{~min}$. (Moghaddam et al., 2000). The traces of toxic residues were removed by three successive washes with distilled water aseptisated for $10 \mathrm{~min}$./washing under continuous agitation (Badea and Săndulescu, 2001; Cachiţă -Cosma et al., 2004).

Artificial nutritive medium were based on MS nutritive medium (Murashige and Skoog, 1962), supplemented by the addition of agar $7 \mathrm{~g} / \mathrm{l}$ and sucrose $20 \mathrm{~g} / \mathrm{l}$ (Cerović and Ružić, 1987; Ružić et al., 2013). BAP $0.5 \mathrm{mg} / \mathrm{l}$, IBA $0.1 \mathrm{mg} / \mathrm{l}$ and $\mathrm{GA}_{3}$ $0.1 \mathrm{mg} / \mathrm{l}$ (Cerović and Ružić, 1987; Hammatt and Grant, 1996/1997; Ružić et al., 2013), were added as growth regulators in the artificial nutritive medium used to produce the shoots. IBA 1.0 mg/l (Clapa et al., 2013) was added as a growth regulator in the artificial nutritive medium used for rooting of shoots. The $\mathrm{pH}$ of each artificial nutritive medium was adjusted to a value of 5.75 (Ružić et al., 2013).

The culture conditions used for incubating biological vegetal material consisted of: temperature of $23 \pm 2^{\circ} \mathrm{C}$ during the lighting periods and
$20 \pm 2^{\circ} \mathrm{C}$ during the period of darkness, the $16 \mathrm{~h}$ photoperiod and light intensity of 1700 luxes. The subcultivations were made at intervals ranging from two to four weeks.

The grafting methods used have as the distinctive feature the position of the grafting section on the longitudinal axis of the grafted structures. In fact, depending on the position of the grafting section three methods of in vitro grafting were tested. Thus, for the M1 method of in vitro grafting the position of the grafting section was perpendicular to the longitudinal axis of the grafted structure (Estrada-Luna et al., 2002). For the $\mathbf{M} 2$ method of in vitro grafting the position of the grafting section was oblique (at an angle of about $45 \pm 5^{\circ}$ ), on the longitudinal axis of the grafted structures. For the M3 method of in vitro grafting the grafting section was obtained by making two cuts so as to create the letter ' $\mathrm{V}$ ' (the bottom of this letter being to the level of the rootstock), by positioning it on the longitudinal axis of the grafted structure (Bourrain and Charlot, 2014). 
The phenotypic unitary structures formed by rootstock or scion, before the grafting, had been immersed with the basal side for $10 \mathrm{sec}$. in aseptisated distilled water or solution of ascorbic acid $0.010 \%$ and $0.015 \%$ citric acid (1:1), to reduce the browning caused by the phenolic compounds that were biosynthesized in order to protect from the stress produced by cutting the biological vegetal material (Thimmappaiah Puthra and Anil, 2002).

The average value and the standard error were individually determined for each analyzed parameter by Duncan's multiple range test $(P<0.05)$. The experimental results are presented as average value \pm standard error (Duncan, 1955).

\section{RESULTS AND DISCUSSION}

From the specialized literature it can be noticed that through in vitro grafting of cherry (Prunus sp.), the current vegetable biotechnology can provide, as compared to ex vitro grafting, a number of additional advantages such as independence from climatic conditions, possibility of achievement all year-round, obtaining a larger number of grafted units (Ružić et al., 2013), recognition of incompatibility phenomena in a shorter time (Pina and Errea, 2008; Pina et al., 2012), facilitating faster diagnosis of viral diseases (Monteuuis, 2012). Thus, the in vitro grafting of cherry (Prunus sp.), may be a way of modeling the existing biological vegetable structures as phenotypic subunitary structures (scion and rootstock), in a phenotypic unitary structure (the grafted vitroplant) that could benefit from the qualities of interest existing in them and, therefore, give rise to a more efficient biological material, from the biological quality point of view, as well as from the economic quality point of view.

This scientific paper presents the experimental results recorded after the conduct and monitoring of experimental research on testing three methods (M1, M2 and M3) of innovating in vitro grafting of cherry (Prunus sp.), from two rootstock varieties (Mazzard and Gisela 6) and three scion varieties (Stella, Severin, Rubin), with the aim of obtaining grafted vitroplants that can be used to establish efficient orchards in Romania. Orchards are able to provide, through innovation in the style of 'Horizon 2020' European Program, competitive products on regional and global markets.

The initial biological material consisted of apical vegetative buds collected from medium cherry branches (Prunus sp.). From the initial inocula were obtained shoots, which, in turn, are source of inoculum, either for obtaining a new set of shoots or for obtaining vitroplants. These vitroplants were processed through sectioning so as they allowed obtaining phenotypic subunitary structures of scion or rootstock type.

Testing the M1 method of innovating in vitro grafting of cherry (Prunus sp.), has led, in the case of the experimental variants that used as rootstock the Mazzard variety, to experimental results based on phenotypic structure of the scion. Basically, the number of grafted vitroplants that had as rootstock the Mazzard variety varied in ascending order between the Stella, Severin and Rubin scion varieties.

Moreover, the experimental variants that had as rootstock the Gisela 6 variety, the number of grafted vitroplants varied according to the phenotypic structure of the scion, ascending between the Stella, Rubin and Severin scion varieties. Thus, from the experimental results it can be noticed that there is a variation in the number of grafted vitroplants according to the compatibility of the phenotypic unitary structure of the rootstock with the one of the scion (Fig. 1).

For the experimental variant that allowed achieving the highest average value of the number of grafted vitroplants through the M1 method the Gisela 6 rootstock variety and the Severin scion variety were used $(45.21 \pm 2.06 \mathrm{c})$. For the experimental variant that allowed achieving the lowest average value of the number of grafted vitroplant through M1 method was used the Mazzard rootstock variety and the Stella scion variety $(11.40 \pm 6.85 \mathrm{~b})$.

Testing the M2 method of innovating in vitro grafting of cherry (Prunus sp.), allowed obtaining experimental results in both experimental variants that had as rootstock the Mazzard variety and experimental variants that had as rootstock the Gisela 6 variety, from which it can be noticed that there is a similar variation in the number of grafted vitroplants depending on the phenotypic structure of the scion involved. Practically, independent of phenotypic structure of the rootstocks, the number of grafted vitroplants 


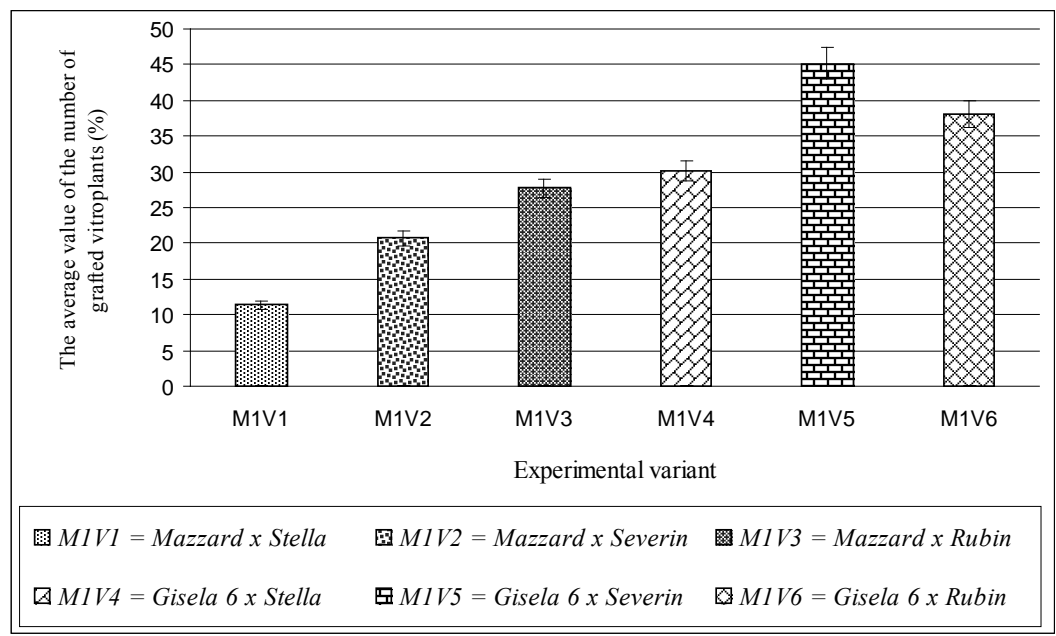

Fig. 1. The average value of the number of grafted vitroplants produced by testing the M1 method of innovating in vitro grafting of cherry (Prunus sp.)

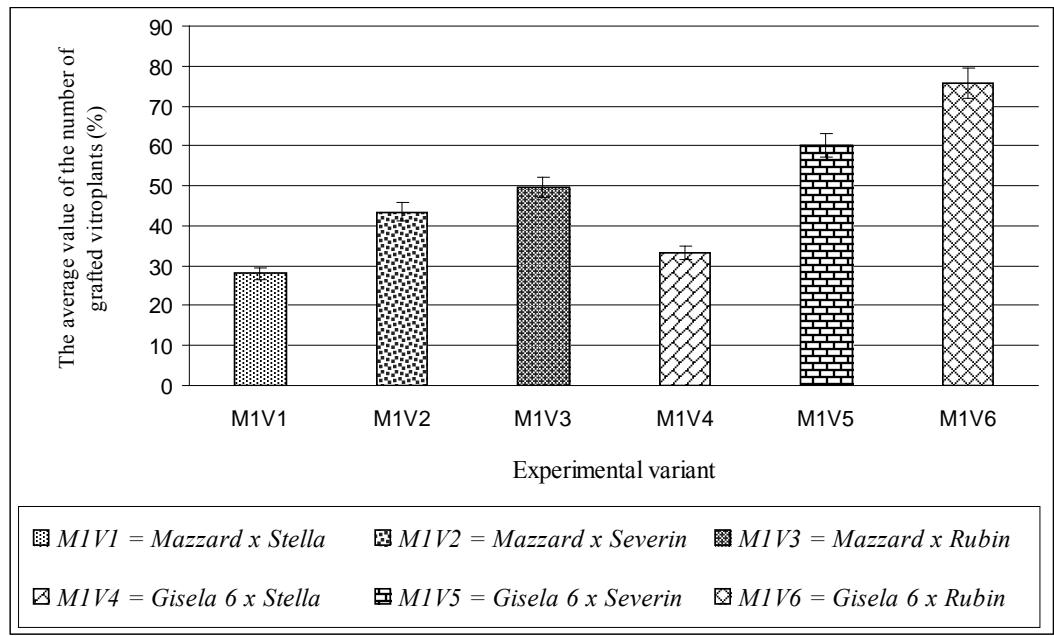

Fig. 2. The average value of the number of grafted vitroplants produced by testing the M2 method of innovating in vitro grafting of cherry (Prunus sp.)

varied in ascending order between the Stella, Severin and Rubin scion varieties. As a result, from the experimental results it can be noticed that the number of grafted vitroplants obtain through the M2 method is independent of the compatibility of the phenotypic unitary structure rootstock and the one of the scion (Fig. 2).

For the experimental variant that allowed recording the highest average value of the number of vitroplants grafted through the M2 method was used the rootstock from the Gisela 6 variety and the scion from the Rubin variety $(75.72 \pm 3.84 a)$.
For the experimental variant that allowed recording the lowest average value of the number of vitroplants grafted through the M2 method was used the rootstock from the Mazzard variety and the scion from the Stella variety $(28.01 \pm 0.16 a)$.

Testing the M3 method of innovating in vitro grafting of cherry (Prunus sp.), has led, in the case the experimental variants that had the Mazzard rootstock variety, to experimental results that varied depending on the phenotypic structure of the scion. Practically, the number of grafted vitroplants that had as rootstock the Mazzard 
variety varied in ascending order between the Stella, Severin and Rubin scion varieties. The experimental variants that had as rootstock the Gisela 6 variety have led to experimental results showing that the number of grafted vitroplants varied in ascending order similar to that recorded for the experimental variants that had as rootstock the Mazzard variety (Fig. 3).

The experimental variant which allowed recording the highest average value of the number of vitroplants grafted through M3 method used the rootstock form the Gisela 6 variety and the scion from the Rubin variety $(81.48 \pm 3.21 \mathrm{a})$. The experimental variant that allowed recording the lowest average value of the number of vitroplants grafted through the M3 method used the rootstock from the Mazzard variety and the scion from the Stella variety $(31.02 \pm 0.48 a)$.

The comparative analysis of the experimental results from testing the three methods of in vitro cherry grafting (Prunus sp.), showed that in the case of experimental variants carried out for the M1 method occurs an obvious dependence of the number of grafted vitroplants on the compatibility of the phenotypic unitary structure of the rootstock with the one of the scion (the number of grafted vitroplants varies in ascending order for the Mazzard rootstock variety between the Stella, Severin and Rubin scion variaties, and for the Gisela 6 rootstock variety between Stella, Rubin and Severin scion varieties). In the case of experimental variant carried out for the $\mathrm{M} 2$ and $\mathrm{M} 3$ methods, this dependence is not so obvious (the number of grafted vitroplants varies in ascending order, for both Mazzard rootstock variety and Gisela 6 rootstock variety, between Stella, Severin and Rubin scion varieties).

However, in the case of the experimental variants carried out for the M2 and M3 methods it may be noted that there is a different relationship between the numbers of grafted vitroplants. This relationship seems to be less dependent on the compatibility of the phenotypic unitary structure of the rootstock with the one of the scion, but more closely linked to the grafting method (the number of grafted vitroplants has a relationship of ascending order from the M2 method towards the M3 method, independent of the rootstock variety or the scion variety).

Taking into account both the recorded experimental results and the multitude of factors involved in the junction area of grafted subunitary structures, it clearly appears the need of the preexistence of a degree of compatibility between them and the chosen grafting method. This degree of compatibility must allow communication on different levels of molecule, cell, tissue and organ organization. This communication must ensure the exchange of elements so as functional vascular connections to be formed.

Forming functional vascular connections is the starting point for mutual support of the

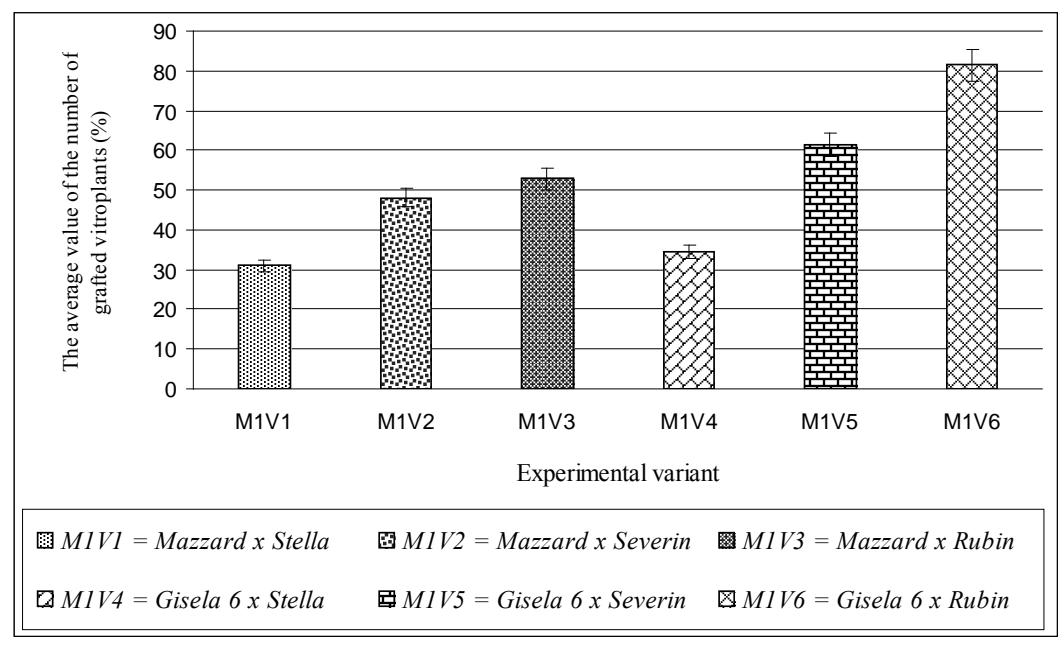

Fig. 3. The average value of the number of grafted vitroplants produced by testing the M3 method of innovating in vitro grafting of cherry (Prunus sp.) 
phenotypic subunitary structures in order to convert them into an autonomous phenotypic unitary structure under in vivo conditions.

When critically analyzing the experimental results and comparing them with those in the specialized literature covered, it can be noticed that the M2 and M3 methods used for in vitro cherry grafting (Prunus sp.), contribute new elements to exploiting the two rootstock varieties (Mazzard and Gisela 6), and three scion varieties (Stella, Severin, Rubin) to obtain grafted vitroplants.

\section{CONCLUSION}

The conduct and monitoring of experimental research on testing methods of innovating in vitro grafting of cherry (Prunus sp.), allowed us to obtain experimental results that indicate the following conclusions:

- the M3 method generated the best experimental results for both grafted vitroplants formed of a rootstock from the Gisela 6 variety and a scion from Rubin variety $(81.48 \pm 3.21 \mathrm{a})$ and for grafted vitroplants formed by combining a rootstock from the Gisela 6 variety and a scion from the Severin variety (61.46 $\pm 7.37 \mathrm{~b})$;

- the Gisela 6 rootstock variety allowed obtaining the highest number of grafted vitroplants with each of the three analyzed scion variaties (Stella, Severin, Ruby), through both M3 method and M2 method;

- the Rubin scion variety allowed obtaining the highest number of grafted vitroplants independent of the rootstock variety (Mazzard and Gisela 6), through both the M3 method and the M2 method.

The experimental results obtained contribute to the innovation of in vitro grafting of cherry (Prunus sp.), showing that through the M3 or M2 method, for the two rootstock varieties (Mazzard and Gisela 6) and for the three scion varieties (Stella, Severin, Rubin), in vitro grafting in order to obtain grafted vitroplants to establish efficient orchards in Romania is possible.

\section{REFERENCES}

1. Amiri ME (2006). Special micrografting technique for cherry (Prunus avium L.). ISHS Acta Horticulturae 764: XXVII International Horticultural Congress - IHC2006: International Symposium on Plant Biotechnology: From Bench to Commercialization. Available at: http://www. actahort.org/books/764/764_18.htm. Accessed 2013 Mar. 08.
2. Badea EM and Săndulescu D (2001). Bio Tehnologii Vegetale. Ed. Fundaţia Biotech, Bucureşti.

3. Bhagwat B and Lane WD (2004). In vitro Shoot Regeneration from Leaves of Sweet Cherry (Prunus avium) 'Lapins' and 'Sweetheart'. Plant Cell, Tissue and Organ Culture (PCTOC), 78(2): 173-181. Available at: http://link.springer.com/article/10.1023\%2FB\%3ATI CU.0000022552.12449.71. Accessed 2013 Mar. 06.

4. Bourrain $L$ and Charlot $G$ (2014). In vitro micrografting of cherry (Prunus avium L. 'Regina') onto 'Piku ${ }^{\circledR} 1$ ' rootstock $[P$. avium $\times(P$. canescens $\times P$. tomentosa $)]$. The Journal of Horticultural Science \& Biotechnology, 89(1): 47-52. Available at: http://www.jhortscib.org/ Vol89/89_1/7. htm. Accessed 2014 Mar. 08.

5. Cachiţă-Cosma D, Deliu C, Rakosy-Tican L and Ardelean A (2004). Tratat de biotehnologie vegetală, Ed. Dacia, ClujNapoca, Vol. I.

6. Canli FA şi Tian L (2008). In vitro shoot regeneration from stored mature cotyledons of sweet cherry (Prunus avium L.) cultivars. Scientia Horticulturae, 116(1): 34-40. Available at: http://www.sciencedirect.com/science/ article/pii/S0304423807003585. Accessed 2013 Mar. 06.

7. Cerović R and Ružić D (1987). Micropropagation of sour cherry (Prunus cerasus L.) cv. Šumadinka. Plant Cell, Tissue and Organ Culture. 9(2): 151-157. Available at: http://link.springer.com/ article/10.1007/BF00044251. Accessed 2013 Mar. 06.

8. Chira L and Asănică A (2010). Cireşul şi vişinul. Ed. a 2-a. Ed. M.A.S.T., București, 7-10, 16, 17, 55.

9. Clapa D, Fira A, Simu M and Horga VC (2013). In vitro propagation of Gisela 5 cherry rootstock. Fruit Growing Research, Vol. XXIX, 100-105.

10. Dejeu L, Petrescu C and Chira A (1997). Hortiviticultură şi protecţia mediului. Ed. Didactică şi Pedagogică, R.A. București, 131-133.

11. Duncan DB (1955). Multiple range and multiple $F$ tests. Biometrics, 11: 1-42.

12. Estrada-Luna AA, López-Peralta C şi Cárdenas-Soriano E (2002). In vitro micrografting and the histology of graft union formation of selected species of prickly pear cactus (Opuntia spp.). Scientia Horticulturae, 92( 3-4): 317-327. Available at: http://www.sciencedirect.com/science / article/pii/S0304423801002965. Accessed 2013 Mar. 08.

13. Hammatt N şi Grant NJ (1996/1997). Micropropagation of mature British wild cherry. Plant Cell, Tissue and Organ Culture, 47(2): 103-110. Available at: http://link.springer. com/article/ 10.1007\%2FBF02318945. Accessed 2013 Mar. 06.

14. FAO (2013). Food and Agriculture Organization of the United Nations, FAOSTAT. Compare Data, Production Value of Agricultural Production. Available at: http:// faostat3.fao.org/faostat-gateway/go/to/compare/Q/ QC/E. Accessed 2013 Mar. 06.

15. Kappel F, Granger A, Hrotkó K and Schuster M (2012). Cherry, Fruit Breeding. Handbook of Plant Breeding, Vol. 8, p. 459-504. Available at: http://link.springer.com/chap ter/10.1007\%2F978-1-4419-0763-9_13. Accessed 2013 Mar. 06. 
16. Liu X, Pijut PM (2008). Plant regeneration from in vitro leaves of mature black cherry (Prunus serotina). Plant Cell, Tissue and Organ Culture (PCTOC), 94 (2): 113-123. Available at: http://link.springer.com/article/10.1007/ s11240-008-9393-x. Accessed 2013 Mar. 01.

17. Moghaddam BE, Mesbah M, Yavari N (2000). The effect of in planta TIBA and proline treatment on somatic embryogenesis of sugar beet (Beta vulgaris L.) Euphytica, 112:151-156. Available at: http://www.springerlink. com/content/h85072251w857r15/fulltext.pdf?page=1. Accessed 2013 Mar. 08.

18. Monteuuis 0 (2012). In vitro grafting of woody species. Propagation of Ornamental Plants, 12(1): 11-24. Available at: http://www.journal-pop.org/2012_12_1_11-24.html. Access 2013 Mar. 01.

19. Murashige $\mathrm{T}$ and Skoog F (1962). A revised medium for rapid growth and bioassays with tobacco tissue cultures. Physiol. Plantarum, 15:473-497.

20. Pina A and Errea P (2008). Influence of graft incompatibility on gene expression and enzymatic activity of UDP-glucose pyrophosphorylase. Plant Science, Vol 174(5): 502-509. Available at:http://www.sciencedirect. com/science/article/pii/S0168945208000174. Acces 2013 Mar. 01.

21. Pina A, Errea P și Martens HJ (2012). Graft union formation and cell-to-cell communication via plasmodesmata in compatible and incompatible stem unions of Prunus spp. Scientia Horticulturae, 143: 144-150. Available at: http://www.sciencedirect.com/science/article/pii/ S0168945208000174. Accessed 2013 Mar. 01.

22. Pârvu C (1997). Universul plantelor, Mică enciclopedie. Ed. Enciclopedică, București, 139-140.

23. Ružić D, Vujović T and Cerović R (2013). Effect of jasmonic acid on in vitro multiplication of low vigorous pear and cherry rootstocks. Fruit Growing Research, Vol. XXIX, 106112.

24. Tang H, Ren Z, Reustle G şi Krczal G (2002). Plant regeneration from leaves of sweet and sour cherry cultivars. Scientia Horticulturae, 93 (3-4): 235-244. Available at: http://www.sciencedirect.com/science/ article/pii/S0304423801003284. Accessed 2013 Mar. 01.

25. Thimmappaiah Puthra GT and Anil SR (2002). In vitro grafting of cashew (Anacardium occidentale L.). Scientia Horticulturae, 92(2): 177-182. Available at: http://www.sciencedirect.com/ science/article/pii/ S0304423801002886. Accessed 2013 Mar. 08.

26. Wang $Y$ and Pijut PM (2014). Improvement of Agrobacterium-mediated transformation and rooting of black cherry. In Vitro Cell. Dev. Biol.-Plant. Available at: http://link.springer.com/ article/10.1007/s11627-0149608-2. Accessed 2014 Mar. 06.

27. Zorić L, Ljubojević M, Merkulov L, Luković J and Ognjanov V (2012). Anatomical Characteristics of Cherry Rootstocks as Possible Preselecting Tools for Prediction of Tree Vigor. Journal of Plant Growth Regulation, 31(3): 320-331. Available at: http://link.springer.com/ article/10.1007\% 2Fs00344-011-9243-7. Accessed 2013 Mar. 01. 